\title{
MORFOLOGIA POLÍNICA DE ESPÉCIES VEGETAIS DO CAMPUS SOSÍGENES COSTA DA UFSB
}

\author{
AUTOR: AGNA SOUZA SILVEIRA \\ CO-AUTOR/ORIENTADOR: JAILSON SANTOS DE NOVAIS
}

Resumo: A palinologia consiste no estudo dos grãos de pólen, esporos e outras estruturas com parede orgânica resistente a ácidos. Esse campo do conhecimento subsidia estudos em diversas outras áreas, como taxonomia e sistemática vegetal, medicina, direito, geologia e apicultura. Para tais aplicações, é necessário identificar corretamente os grãos de pólen, o que se dá a partir da consulta a catálogos e a laminários de referência nas palinotecas, confeccionados por meio da coleta e do processamento de grãos de pólen, por meio da acetólise, e posterior montagem em lâminas. Estas são levadas ao microscópio óptico e, assim, os grãos de pólen são mensurados e descritos de acordo a sua morfologia. Para identificar tipos polínicos em nível de espécie, é muito útil compará-los com grãos de pólen em lâminas depositadas em palinotecas, o que exprime a importância de uma coleção palinológica. Sendo assim, o objetivo desse estudo foi caracterizar a morfologia polínica de espécies de Leguminosae ocorrentes no câmpus Sosígenes Costa da UFSB, em Porto Seguro (BA), especialmente aquelas com potencial apícola. Foram levantadas as espécies de leguminosas já catalogadas no referido câmpus, que corresponde ao Jardim Botânico Floras (JB Floras), por meio de consulta ao trabalho de Pinto et al. (2019), priorizando aquelas espécies com potencial apícola, conforme a literatura, a fim de contribuir com estudos melissopalinológicos em andamento na UFSB. No total, foram descritas 14 espécies de Leguminosae ocorrentes no JB Floras, com base na literatura palinológica, pertencentes a 11 gêneros: Andira, Cajanus, Centrosema, Chamaecrista, Crotalaria, Desmodium, Leucaena, Mimosa, Peltophorum, Senna e Stylosanthes. As espécies estão divididas nas subfamílias Caesalpinioideae (8 spp.) e Papilionoideae (6 spp.). Destas, apenas Crotalaria lanceolata E. Mey. ainda não foi descrita palinologicamente, evidenciando uma lacuna a ser preenchida por trabalhos futuros. A morfologia polínica variou bastante entre as espécies. Foram constatadas unidades de dispersão desde mônades até tétrades; as aberturas variaram de 3 a 5 cólporos; a ornamentação da exina apresentou-se como microreticulada, reticulada, reticulada heterobrocada, insulada, microfoveolada, granulada, psilada e heteroreticulada. Conclui-se que o campus Sosígenes Costa é rico em espécies vegetais com potencial apícola que podem ser exploradas palinologicamente.

Palavras-chave: Palinologia, morfologia, flora apícola, campus Sosígenes Costa. 